\title{
PENGEMBANGAN KARAKTER TANGGUNG JAWAB ANAK MELALUI KEGIATAN COOKING CLASS
}

\author{
Halimatussadiah ${ }^{1}$ \\ Edi Rohendi ${ }^{2}$ \\ Leli Halimah ${ }^{3}$
}

\begin{abstract}
ABSTRAK
Penelitian ini dilatarbelakangi oleh pengembangan karakter tanggung jawab anak di dalam lingkungan sekolah yang kurang optimal seperti hal anak tidak menyimpan kembali barangbarang yang telah digunakan. Tujuan dari penelitian ini adalah untuk mengetahui hasil pengembangan kemampuan bertanggung jawab anak melalui kegiatan cooking class pada anak kelompok B di TK Mutya Agni. Penelitian menggunakan metode Penelitian Tindakan Kelas model John Elliot yang dilaksanakan tiga siklus dan setiap siklus terdiri dari tiga tindakan. Instrumen yang digunakan adalah pedoman observasi, penilaian peforma, catatan lapangan, catatan anekdot, dan dokumentasi. Hasil penelitian menunjukkan 1) penggunaan bahan-bahan sesuai petunjuk, 2) menyelesaikan tugas sampai selesai, 3) menyelesaikan tugas dengan tepat waktu, 4) mengikuti aturan selama kegiatan cooking class, 5) merapihkan alat, tempat, dan bahan yang telah digunakan. Kelima indikator tersebut mengalami peningkatan pada setiap siklusnnya. Hasil presentasi pengembangan karakter tanggung jawab anak pada siklus I sebesar $0 \%$ hal ini dikarenakan anak masih pada tahap BSH, pada siklus II sebesar $50,42 \%$, dan pada siklus III sebesar 89,89\%. Karakter tanggung jawab anak meningkatkan setelah diberikan kegiatan cooking class. Oleh karena itu, hasil penelitian ini dapat dijadikan sebagai salah satu kegiatan yang dapat mengembangkan karakter anak.
\end{abstract}

Kata Kunci : karakter tanggung jawab anak, cooking class, taman kanak-kanak, PTK

\footnotetext{
${ }^{1}$ halimatussadiah 135@gmail.com

${ }^{2}$ Edi Rohendi

${ }^{3}$ Leli Halimah
} 


\section{A. PENDAHULUAN}

Pendidikan anak usia dini merupakan pendidikan yang paling mendasar yang mempunyai pengaruh di masa selanjutnya. Begitu juga dengan pendidikan karakter yang sangat penting di bina sejak dini salah satunya adalah karakter tanggung jawab. Dalam Peraturan Menteri Pendidikan dan Kebudayaan Republik Indonesia nomor 137 tahun 2014, salah satu tingkat pencapaian perkembangan anak usia 5-6 dalam aspek perkembangan sosial emosional dalam sikap tanngung jawab anak salah satunya adalah mentaati aturan kelas, mengikuti aturan dalam setiap kegiatan, mampu menjaga dirinya sendiri. Dalam sikap tanggung jawab ini anak usia dini belajar bagaimana caranya menghormati dirinya sendiri dan orang lain seperti halnya menjaga kebersihan lingkungan sekitar dan menjaga barang yang dimilikinya, menyimpan kembali peralatan bermain yang telah digunakan, menyimpan tas pada tempatnya, mengikuti kegiatan dengan baik sampai selesai dan lain sebagainya. Dan ketika anak sudah mampu mengerjakan tugasnya maka rasa percaya dirinya pun akan berkembang seiring berjalannya waktu

Berdasarkan hasil observasi fakta di lapangan menunjukkan bahwa masih banyak anak usia dini khususnya anak yang usia 5-6 tahun belum mampu memiliki karakter tanggung jawab anak. Misalnya terdapat anak tidak menyimpan kembali barang yang telah digunakannya, anak yang tidak mau menyelesaikan tugasnya, anak yang tidak mau mengerjakan tugasnya secara mandiri. Pembinaan karakter yang biasanya dilakukan oleh guru terhadap anak didiknya hanya melalui kegiatan bercakap-cakap saja dan hanya sekedar memberikan motivasi guru terhadap anak untuk menyelesaikan tugasnya. Terkadang juga ada seorang guru yang acuh ketika terdapat anak yang membutuhkan bantuan dalam pembinaan karakter. Pembinaan dan pembentukkan karakter ini dapat dilakukan berbagai cara seperti halnya dengan menghadirkan kegiatan yang menyenangkan yang di dalamnya terdapat beberapa aturan yang setiap anak perlu untuk mengikuti aturan dan petunjuk yang diberikan oleh guru. Salah satu kegiatan yang dipilih oleh peneliti untuk pengembangan karakter tanggung jawab adalah dengan kegiatan cooking class.

Berdasarkan latar belakang yang telah dipaparkan, penelitian yang dilakukan adalah penelitian tindakan kelas dengan judul "Peningkatan Karakter Tanggung Jawab Anak melalui Kegiatan Cooking Class", dengan rumusan masalah adalah sebagai berikut :

1. Bagaimana proses mengembangkan karakter tanggung jawab anak melalui kegiatan cooking class di TK Mutya Agni?

2. Bagaimana hasil pengembangan karakter tanggung jawab anak melalui kegiatan cooking class di TK Mutya Agni? Berdasarkan rumusan masalah tersebut maka tujuan penelitian ini adalah sebagai berikut :

1. Meningkatkan proses pengembangan karakter tanggung jawab anak di TK Mutya Agni

2. Mengidentifikasi hasil pengembangan karakter tanggung jawab anak melalui kegiatan cooking class di TK Mutya Agni.

Setiap individu memiliki karakter sebagai perangai dalam kehidupan sehari- hari. Menurut Direktorat Pembinaan PAUD (2012) mengemukakan bahwa karakter merupakan tabiat atau kebiasaan untuk melakukan yang baik. Selain itu menurut Fauzi dkk (2013) karakter merupakan penanaman nilai-nilai karakter di lingkungan sekolah yang terdiri dari pengetahuan, kesadaran dalam melakukan tindakan yang berupa nilai- nilai baik itu kepada Tuhan YME, maupun terhadap diri sendiri, lingkungan, keluarga dan sesama warga negara Indonesia agar menjadi manusia yang berkualitas. Hal ini sejalan dengan pendapat Berkowitz dan Bier (2005) dalam penelitiannya berbasis pendidikan karakter. Pengertian karakter itu di lihat dari tujuan dari diadakannya pendidikan karakter adalah untuk pengembangan karakter anak. Dapat disimpulkan bahwa pendidikan karakter adalah usaha yang dilakukan agar setiap 
orang memiliki karakter baik dan dapat mengambil keputusan.

Menurut Fauzi dkk (2013) pendidikan karakter merupakan usaha yang dilakukan untuk mengembangkan dan mendidik seseorang agar memiliki karakter yang baik dalam perilaku, budi pekerti dan akhlak sehingga menjadi lebih baik. Sedangkan pengertian tentang pendidikan karakter menurut Megawangi (2015, him. Ill) adalah usaha yang dilakukan untuk mendidik anak-anak agar dapat mengambil keputusan dengan bijak dan mempraktikannya dalam kehidupan sehari-hari, sehingga anak dapat memberikan kontribusi yang positif kepada lingkungannya. Nilai-nilai karakter karakter yang perlu ditanamkan kepada anak-anak adalah nilai-nilai universal yang mana seluruh agama, tradisi dan budaya pasti menjunjung tinggi nilai tersebut. Pengertian pendidikan karakter menurut Megawangi sama hal nya dengan pendapat Kesuma (dalam Barnawi dan Arifin, 2012, him. 23) "pendidikan karakter merupakan suatu bentuk tindakan yang dapat diaplikasikan dalam kehidupan sehari- hari yang mempunyai ciri dapat mengambil keputusan dengan bijak".

Adapun 9 pilar karakter mulia IHF menurut Megawangi (2015) yang harus dimiliki oleh setiap individu dalam pendidikan karakter di sekolah maupun di lingkungan keluarga ataupun masyarakat, diantaranya : 1) cinta kepada Tuhan dan terhadap ciptaan-Nya, 2) memiliki sikap tanggung jawab, disiplin dan mandiri, 3) memiliki sifat jujur, amanah dan berkata bijak, 4) selalu hormat, santun dan pendengar yang baik, 5) memiliki kasih sayang, peduli dan kerja sama, 6) percara diri, kreatif dan pantang menyerah, 7) adil dan baik dalam memimpin, 8) baik dan rendah hati, 9) toleran, cinta damai dan bersatu.

Adapun prinsip-prinsip pendidikan karakter Menurut Derektorat Pembinaan PAUD (2012) yang perlu diketahui dan dilaksanakan oleh para pendidik dan lembaga PAUD, yaitu pendidikan dilakukan secara menyelurah maksudnya adalah terintegrasi dengan seluruh aspek perkembangan anak. Para pendidik pun mempunyai peranan yang penting yaitu senantiasa memberikan contoh teladan kepada anak didiknya. Teladan yang baik sangat perlu pertontonkan oleh seorang pendidik yang hebat. Karena pada dasarnya anak usia dini mempunyai ciri khas yaitu sebagai peniru ulung dan perekam yang kuat. Selain itu, agar tercapainya pendidikan karakter yang dapat dilakukan oleh guru adalah bekerja sama dengan para orang tua, masyarakat untuk menyelaraskan penanaman pendidikan karakter di lingkungan sekolah dengan pendidikan karakter di lingkungan keluarga agar pendidikan karakter yang ditanamkan berjalan sesuai yang diharapkan. Begitu pun dengan penilaian sangat berpengarah dalam pendidikan karakter anak untuk mengukur sejauh mana anak dapat mempunyai nilai-nilai karakter yang diharapkan tertanam sejak usia dini. Dengan adanya penilaian, apabila anak belum mempunyai karakter yang baik maka akan terlihat dan menjadi evaluasi para pendidik selanjutnya untuk mengoptimalkan kembali pendidikan karakter dengan mengembangkan model pembelajaran anak yang lebih kreatif lagi.

Tujuan pendidikan karakter menurut Kesuma dkk (2013) adalah memberikan penguatan dan pengembangan nilai karakter yang akan tertanam dalam diri anak sehingga menjadi perilaku yang seutuhnya. Tujuan yang kedua yaitu pendidikan karakter di sekolah sebagai usaha untuk mengubah perilaku anak dari negatif di rubah menjadi perilaku positif. Tujuan yang ketiga yaitu pendidikan karakter dalam pengaplikasiannya harus disertai dengan kolaborasi antara pihak sekolah maupun keluarga agar pendidikan karakter tertanam seutuhnya.

Lingkungan pun mempunyai peranan yang sangat penting dalam proses tumbuh kembang anak. Begitu halnya dengan pembentukan karakter anak sejak dini yang sangat dipengaruhi oleh peran lingkungan. Apabila anak tinggal di lingkungan yang mendukung anak untuk pembentukan karakter maka anak mempunyai karakter baik. Berbeda halnya dengan anak yang tinggal di lingkungan yang tidak mendukung untuk pembentukan karakter 
maka anak mempunyai karakter yang tidak sesuai dengan perilaku sehari-hari. Hal ini sejalan menurut pendapatnya Wening (2012) yang paling terpenting peran lingkungan untuk membentuk karakter anak itu diantaranya keluarga, sekolah, teman sebaya dan media massa. Salah satu hasil penelitiannya peran keluarga mempunyai peran yang cukup baik dalam pembentukan karakter. Dikarenakan keluarga merupakan sekolah pertama dan paling utama bagi anak dalam membantu proses tumbuh kembang anak maupun pembentukan karakter.

Menurut Indonesia Heritage Foundation (dalam Megawangi, 2015) sikap tanggung jawab merupakan karakter yang selaknya ditanamkan sedini mungkin. Mengapa demikian, karena karakter yang berkualitas adalah karakter yang dibentuk dan dibina sedari dini mungkin. Karakter tanggung jawab merupakan suatu karakter yang harus dimiliki oleh anak agar menjadi pribadi yang bertanggung jawab di masa yang akan datang. Kegagalan penanaman karakter akan menyebabkan masalah yang timbul di masa selanjutnya. Selain itu menurut Lickona (2013) berpendapat bahwasanya tanggung jawab adalah usaha yang dilakukan oleh individu untuk menjaga dirinya sendiri maupun menjaga diri orang lain sehingga ia menjadi individu yang dapat menjalankan kewajibannya untuk ikut serta dalam kegiatan yang diselenggarakan di masyarakat sehingga terciptalah kehidupan yang lebik baik lagi dengan masyarakat.

Ada banyak cara untuk meningkatkan karakter tanggung jawab anak. Salah satu cara yang dapat dilakukan yaitu dengan mengajak anak untuk berkontribusi dalam kegiatan memasak. Memasak merupakan suatu bentuk kegiatan yang menyenangkan untuk anak. Karena disesuaikan dengan prinsip pembelajaran untuk anak bahwasanya pembelajaran yang menyenangkan merupakan pembelajaran yang tepat untuk anak usia dini. Ketika memasak telah masuk ranah sekolah maka dinamakan sebagai cooking class yaitu kegiatan memasak yang dilakukan di kelas. Hal ini sejalan dengan pendapatnya Borich dan Tombari (dalam Fadlillah dan Khorida, 2013, hlm 129) yang mengungkapkan bahwa "gaya belajar anak tidak terlepas dari hal yang dapat menarik minat atau menyenagkan anak." Menurut Einon (2006) mengemukakan bahwa dengan memasak mengajarkan anak untuk membantu segala aktivitas yang dilakukan di dapur dan merupakan cara yang terbaik untuk memberikan latihan mengikuti petunjuk sekaligus untuk memperkenalkan berbagai konsep seperti berat dan volume dan meningkatkan ketertarikan pada hal- hal yang alami. (2006) adapun yang dapat dipelajari oleh anak ketika ia berkontribusi memasak di dapur diantaranya : 1) untuk mengikuti instruksi sederhana dan bekerja sampai selesai, 2) untuk merasa bangga pada apa yang dapat ia lakukan, belajar mengurus sesuatu, membantu dan bekerja dengan orang lain, 3) untuk menggunakan cangkir pengukur atau timbangan, 4) untuk mempertahankan keterkaitannya terhadap satu hal selama beberapa minggu, 5) untuk mengamati dan memperhatikan hal-hal terperinci.

\section{B. METODE}

Penelitian dilaksanakan di TK Mutya Agni pada kelompok B3 usia 5-6 tahun dengan jumlah anak 20 orang. Metode penelitian ini menggunakan metode Penelitian Tindakan Kelas. PTK adalah salah satu cara untuk memperbaiki dan meningkatkan proses pembelajaran dalam pembinaan karakter tanggung jawab di Taman Kanak-kanak. Menurut Mulyasa (2013, him. 11) "PTK merupakan suatu upaya untuk mencermati kegiatan belajar sekelompok peserta didik dengan memberikan sebuah tindakan (treatment) yang sengaja dimunculkan." Sejalan menurut Abidin (2011, him. 217) penelitian tindakan kelas merupakan "penelitian yang dilakukan untuk memecahkan masalah, mengkaji langkah pemecahan masalah itu sendiri, dan atau memperbaiki proses pembelajaran secara berulang atau bersiklus." Desain penelitian yang akan digunakan dalam penelitian ini adalah model Elliot. 
Desain model Elliot ini digunakan untuk menghasilkan penelitian yang lebih baik. Dengan 3 siklus dan setiap siklusnya terdiri dari 3 tindakan.

\section{PEMBAHASAN}

Penelitian ini dimulai dari siklus 1 sampai siklus 3. Peneliti merancang kegiatan pembelajaran, menyediakan alat dan bahan yang digunakan selama kegiatan cooking class. Setelah merencanakan tindakan penelitian, peneliti melakukan penelitian dengan 3 siklus dan setiap siklusnya terdapat 3 tindakan. Peneliti melakukan refleksi setelah melakukan penelitian. Refleksi ini digunakan peneliti untuk memonitoring kekurangan pada setiap siklusnya dan dijadikan bahan perbaikan pada penelitian selanjutnya. Kegiatan penelitian ini dilakukan sebagai salah satu cara mengembangkan karakter tanggung jawab anak pada usia 5-6 tahun. Adapun indikator yang ingin dicapai adalah anak mampu menggunakan bahan sesuai dengan petunjuk guru, anak mampu menyelesaikan tugas sampai selesai, anak mampu menyelesaikan tugas tepat waktu, anak mampu mengikuti aturan kegiatan cooking class, dan anak mampu merapihkan alat, bahan, dan tempat yang telah digunakan.

\section{Siklus I}

Pada tindakan 1 ini, anak-anak membuat bola-bola coklat. Pada tindakan 1 ini, anakanak belum sepenuhnya mampu mengikuti setiap petunjuk yang guru berikan. Terdapat anak yang masih mengobrol saat guru memberikan petunjuk cara membuat bola-bola coklat. Pada tindakan 2, anak-anak menghias roti tawar dengan berbagai selai secara bergiliran dengan teman sekelompoknya. Anak-anak mengikuti petunjuk guru dalam mengolesi roti tawar dengan berbagai selai. Hal ini bertujuan agar anak mampu mengikuti setiap petunjuk guru dan mengikuti aturan dalam menghias roti tawar. Selanjutnya pada tindakan 3, anak-anakanak membuat jasuke. Anak-anak membuat jasuke dengan cara berkelompok. Setiap kelompoknya diberikan bahan-bahan untuk membuat jasuke yang sama dengan kelompok lain.

Pada siklus I, peneliti melaksanakan kegiatan cooking class hasilnya adalah anak mampu mengikuti petunjuk guru sesuai dengan yang diharapkan guru. Berikut presentase karakter tanggung jawab :

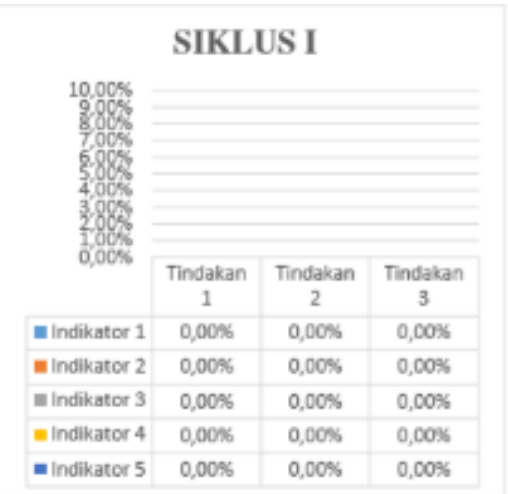

\section{Gambar 4.4 Pengembangan Karakter Tanggung Jawab Anak}

Berdasarkan grafik diatas, pada setiap tindakan dalam melakukan kegiatan kegiatan cooking class belum terlihat pengembangan karakter tanggung jawab yang optimal, walaupun ada beberapa anak yang mulai mampu menunjukkan karakter tanggung jawab anak sesuai dengan indikator yang telah dibuat akan tetapi dirasa belum optimal. Pada setiap indikator anak, $0 \%$ anak sudah mampu mengikuti kegiatan cooking class secara baik sesuai dengan 
petunjuk guru. Hal ini dikarenakan anak rata-rata masih pada tahap BSH (Berkembang Sesuai Harapan), belum ada anak yang mampu mencapai kriteria BSB (Berkembang Sangat Baik).

\section{Siklus II}

Dalam pelaksanaan siklus II ini peneliti mencoba menghadirkan alat untuk memasak. Pada tindakan 1 anak- anak membuat pudding roti tawar pisang keju. Peneliti memberitahu kepada anak bahan-bahan apa saja yang digunakan dan langkah-langkah membuat pudding. Peneliti membagi anak ke dalam empat kelompok dan setiap kelompoknya memiliki tugas yang berbeda. Pada saat kegiatan membuat pudding ini, anak-anak terlihat mampu mengikuti selurah petunjuk guru. Pada tindakan 2, anak- anak membuat agar-agar berbentuk binatang dengan cara bergiliran perkelompok. Selanjutnya pada tindakan 3, peneliti mernyajikan kegiatan yang lebih menarik untuk anak yaitu membuat getuk lindri perkelompok dengan diberikan tugas dan bahan-bahan yang sama. Berikut hasil presentase karakter tanggung jawab anak.

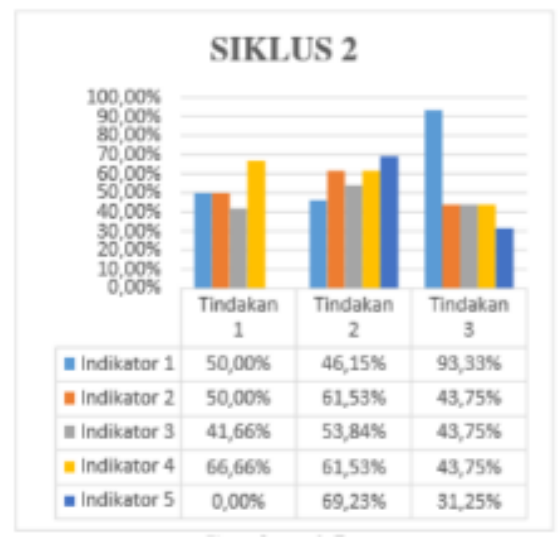

Gambar 4.5 Pengembangan Karakter Tanggung Jawab Anak

Berdasarkan hasil penilaian peforma pada siklus II, terlihat adanya peningkatan penuranan pada setiap indikator. Pada indikator 1 anak sudah mampu menggunakan bahanbahan sesuai dengan petunjuk guru. Pada indikator 2 anak sudah mampu menyelesaikan tugas sampai selesai dengan baik. Pada indikator 3 anak sudah mampu menyelesaikan tugas tepat waktu dengan baik. Pada indikator 4 anak sudah mampu mengikuti aturan dalam kegiatan cooking class. Pada indikator 5 anak sudah mampu merapihkan kembali alat, tempat, dan bahan yang telah digunakan.

\section{Siklus III}

Kegiatan yang dilakukan pada tindakan 1 adalah membuat jus buah naga dengan menghadirkan blender. Pada tindakan 2, peneli. Kegiatan yang dilakukan pada tindakan 2 yaitu membuat sop buah, setiap kelompok diberi tugas memotong buah-buahan yang berbeda sesuai dengan petunjuk guru. Selanjutnya pada tindakan 3, anak membuat es jeruk dengan menghadirkan alat memeras jeruk yang bertujuan agar anak mau terlibat dalam pembuatan es jeruk. Berikut hasil rata-rata keterampilan emosi anak pada siklus III. 


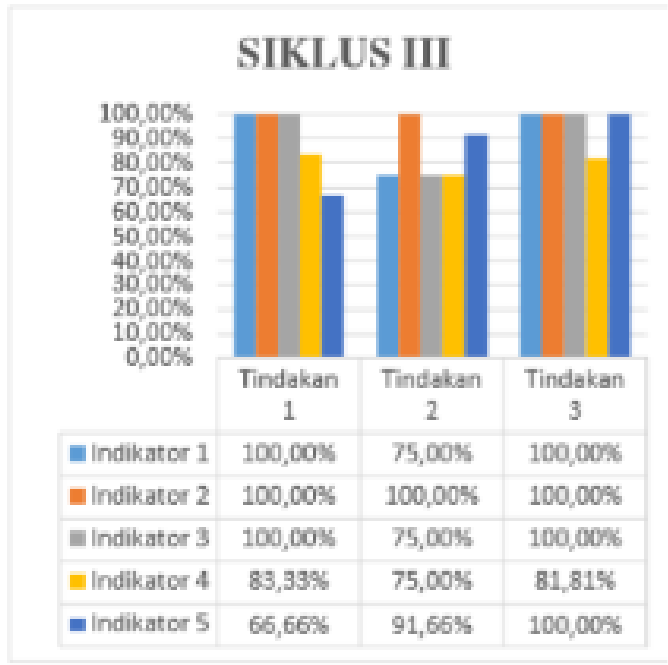

Gambar 4.6 Pengembangan Karakter Tanggung Jawab Anak

Berdasarkan hasil penilaian peforma pada siklus III, terlihat adanya peningkatan pada setiap indikator. Pada indikator 1 anak sudah mampu menggunakan bahan-bahan sesuai dengan petunjuk guru. Pada indikator 2 anak sudah mampu menyelesaikan tugas sampai selesai dengan baik. Pada indikator 3 anak sudah mampu menyelesaikan tugas tepat waktu dengan baik. Pada indikator 4 anak sudah mampu mengikuti aturan dalam kegiatan cooking class. Pada indikator 5 anak sudah mampu merapihkan kembali alat, tempat, dan bahan yang telah digunakan. Anak pada siklus III ini mengalami peningkatan yang sangat pesat dikarenakan perencanaan pembelajaran yang baik untuk menunjang pengembangan karakter tanggung jawab anak.

\section{DAFTAR PUSTAKA}

Abdulhak, I. \& Suprayogi, U. (2012). Penelitian tindakan dalam pendidikan nonformal. Jakarta : RajaGrafindo Persada

Abidin, Y. (2011). Penelitian pendidikan clalam gamitan pendidikan dasar clan PAUD. Bandung : Rizqi Press

Barnawi dan Arifin. (2012) Strategi clan Kebijakan Pembelajaran Pendidikan Karakter. Arruzz Media

Berkowitz, M. W., dan Bier, M. C. (2005). Character education. Jurnal: Educational Leadership, hlm. 72-85.

Departemen Pendidikan dan Kebudayaan. (2014). Peraturan pemerintah no 137 standar nasional pendidikan anak usia dini. Jakarta : Depdikbud

Direktorat Pembinaan PAUD. (2012). Pedoman Pendidikan Karakter pada Pendidikan Anak Usia Dini, Jakarta : Dirjen PAUD.

Einon, D. (2006). Permainan Kreatif untuk Anak-anak. Batam: Karisma Publising Group.

Fadlillah, M., Khorida, L. M. (2013). Pendidikan Karakter Anak Usia Dini. Jogjakarta: ArRuzz Media

Fauzi, dkk (2013). Peran guru pendidikan pancasila dan kewarganegaran dalam upaya pembentukan karakter peserta didik. Jurnal: PPKN UNJ Online, 1 (2), hlm 115.

Kesuma, D., Triatna, C., dan Permana, J. (2013). Pendidikan Karakter Kajian Teori dan 
Praktek di Sekolah. Bandung: Remaja Rosdakarya.

Megawangi, R. (2012). Menyemai Benih Karakter. Depok: Indonesia Heritage Foundation. Megawangi R. (2015). Pendidikan Karakter. Depok: Indonesia Heritage Foundation.

Mulyasa, E. (2013). Praktik penelitian tindakan kelas. Bandung: ROSDA

Wening, S. (2012). Pembentukan karakter bangsa melalui pendidikan nilai. Jurnal: Jurnal Pendidikan Karakter, 2 (1), hlm. 55-66.

Barnawi. (2015). Format Jogjakarta : Ar-Ruzz 